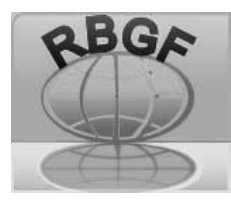

ISSN:1984-2295

\section{Revista Brasileira de Geografia Física}

Homepage: www.ufpe.br/rbgfe

\title{
Evaluation of land use effects on the natural landscapes of São Carlos - São Paulo, Brazil
}

\author{
Diego Peruchi Trevisan ${ }^{1}$; Luiz Eduardo Moschini ${ }^{1}$; Polyanna da Conceição Bispo ${ }^{2}$, Heiko Balzter $^{2}$
}

${ }^{1}$ Center for Biological and Health Sciences, Environmental Sciences Department. Highway Washington Luís, Km 235 - São Carlos, SP - Brazil. ${ }^{2}$ Leicester Institute for Space and Earth Observation, Centre for Landscape and Climate Research, School of Geography, Geology and the Environment, University of Leicester, Bennett Building, University Road, LE1 7RH, Leicester- United Kingdom. Correspondent author pdcb1 @ leicester.ac.uk; hb91@1eicester.ac.uk.

Received paper in $08 / 14 / 2018$ and accept in $11 / 14 / 2018$

\begin{abstract}
A B S T R A C T
Anthropogenic actions influence most landscapes and the resulting mosaic is a mix of natural and anthropogenic landscape elements that vary in size, shape, pattern and structure. Measures of landscape patterns can quantitatively analyze landscape structure. This study aimed to analyze the effects of land use and land cover on the spatial and temporal patterns in the landscapes of São Carlos, Brazil, from 2003 to 2013. A set of Environmental Quality Indices (EQI) was used to analyze the susceptibility of the ecological components to the effects of human activities. The Environmental Quality Index of Water Resources, the Environmental Quality Index of Vegetation, and the Environmental Vulnerability Index were used to assess the condition of ecological sustainability of the landscape. A reduction in the areas of native vegetation over time was identified with loss of $31 \%$ in ten years, representing over 3,067 ha, an expansion of agricultural areas of $40 \%$ and consequently a reduction of the environmental quality in the landscapes of São Carlos. These impacts compromise ecosystem structure and ecosystem services, e.g. through impacts on soils that support vegetation cover as the major sources of energy for terrestrial life. The observed intensification of anthropogenic activities and the corresponding reduction of natural areas often lead to the loss of biodiversity and the benefits that its ecosystem services provide to people.
\end{abstract}

Keywords: Landscape analysis; Landscape indices; Environmental quality; Environmental planning.

\section{Avaliação dos efeitos do uso da terra na paisagem natural de São Carlos - São Paulo, Brasil}

\section{R E S U M O}

As ações antropópicas influenciam a maioria das paisagens e o mosaico resultante é uma mistura de elementos paisagísticos naturais e antropogênicos que variam em tamanho, forma, padrão e estrutura. As análises dos padrões de paisagem podem avaliar quantitativamente a estrutura da paisagem. Este estudo teve como objetivo analisar os efeitos do uso e cobertura da terra nos padrões espaciais e temporais na paisagem de São Carlos, Brasil, de 2003 a 2013 . Um conjunto de Índices de Qualidade Ambiental (EQI) foram utilizados para analisar a suscetibilidade dos componentes ecológicos sob os efeitos das atividades humanas. O Índice de Qualidade Ambiental dos Recursos Hídricos, o Índice de Qualidade Ambiental da Vegetação e o Índice de Vulnerabilidade Ambiental foram utilizados para avaliar a condição de sustentabilidade ecológica da paisagem. Uma redução nas áreas de vegetação nativa ao longo do tempo foi identificada com perda de $31 \%$ em dez anos, representando 3.067ha, com uma expansão de áreas agrícolas de $40 \%$ e consequentemente uma redução da qualidade ambiental nas paisagens de São Carlos. Estes impactos comprometem a estrutura do ecossistema e os serviços ecossistêmicos, por exemplo. através de impactos nos solos que suportam a cobertura vegetal como as principais fontes de energia para a vida terrestre. A intensificação observada das atividades antrópicas e a correspondente redução das áreas naturais frequentemente levam à perda da biodiversidade e aos benefícios que os serviços ecossistêmicos proporcionam às pessoas.

Palavras-chave: Análise de paisagem; Índices de paisagem; Qualidade ambiental; Planejamento Ambiental.

\section{Introduction}

The changes in Brazil's landscapes have intensified in the last years due to economic development and changes in environmental laws such as the Brazilian Forest Code (BRASIL, 2012). The expansion of urban and agricultural areas has increased fragmentation, deforestation and degradation process in natural forests, resulting in a large loss of biodiversity and impacts in climate change in the different landscapes (Duffy et al., 2017).

The landscape can be considered a spatial unit whose heterogeneity is mainly modified by the 
relationship established between society and nature, producing a setting characterized by the fragmentation or connection among its elements. Human actions influence most landscapes and the resulting mosaic is a mix of natural and anthropogenic landscape elements that vary in size, shape, structure and arrangement (Goerl et al., 2011; Mateiro et al., 2018).

The failure to plan these human and environment interactions often results in habitat degradation, soil erosion, and impoverishment of natural ecosystems. These processes compromise the landscape structure and consequently threaten environmental sustainability by impacting natural capital, which provides ecosystem services for human wellbeing (Turner, 1989; Dos Santos, 2011).

Landscape structure is a result of physical, biological, political, economic and social interactions that are fragmented or connected by different land uses (Turner et al., 1998; Comono et al., 2016). Analyzing landscape structure is necessary in order to reach environmental conditions that are supported by the explicit spatial structure of landscape units and to enable informed environmental planning (Gardner; O'neill, 1991; Pena et al., 2018) and measures to describe their patterns can be applied for a quantitative analysis of landscape structure

In Sao Carlos, agricultural land use has grown without any environmental planning (Trevisan, 2015) and consequently there is a need to study the impacts of these activities and how they have modified the landscape structure.

Environmental decision-making and policy-making are based on the quantification of environmental conditions such as land use and land cover, the status of conservation, and the ability of the landscape to recover. In recent years, explicit demand has been put on the scientific community to produce such indicators to direct conservation investments. The need for answers on short timescales has led scientists to attempt surrogate measures calculated on the basis of available or easily measurable indicators, which are being developed to serve as a basis for critical decisionmaking, often involving some of the most important ecosystems on Earth (De Leo; Levin,1997; Dong; Hauschild, 2017).

The development of methods for the quantification of the landscape structure is a prerequisite for understanding the relationships between patterns and processes in the landscape, revealing their hierarchical organization. In recent decades, there has been a quest for new quantitative methods that can analyze patterns, determine the importance of spatial processes and develop reliable models (Turner; Gardner, 1991; Ridding et.al, 2018).

Author such as Turner (1987); O'Neill et al., (1988); Gustafson; Parker (1992), McGarigal; Marks (1995), Schumaker (1996) and Malcolm et al., (2017) have been developing a large number of indices and descriptive measures of spatial landscape patterns. Modelling establishes itself as an excellent ally to obtaining knowledge and generating hypotheses in landscape ecology and population issues.

These measures have been utilized to compare the composition and structure of different landscapes, to identify changes over time, to explore the effects of different configurations imposed by alternative management practices on the likelihood of disturbances and also as independent variables in explanatory models of abundance and species diversity in aspects of function of landscape structure as the size and distance between forest fragments (Franklin; Forman, 1987; Turner; Simard, 2017).

An example is the work developed by Inkoom et al., (2018) that aimed at identifying a core set of landscape metrics for assessing potential ecosystem services provision and for application in spatial planning in the highly anthropogenically dominated landscapes of the Sudanian Savanna region. Twenty-two metrics for services assessment and spatial planning selected from the literature were calculated. They employed Spearman's rank correlation and multivariate principal component analysis factor analysis to identify redundancies between the assessed metrics and select the most promising ones.

In this context, this reality reveals the importance of adequate territory planning and studies that aiming to the improvement of environmental and consequently urban quality, where environmental functionalities need to be valued significantly (Baró et al., 2017). This study aimed to analyze the effects of land use intensity and land cover on the spatial and temporal patterns of the landscape around the city of São Carlos in Brazil between the years 2003 and 2013, using landscape indices.

\section{Material and methods}

Study area

The municipality of São Carlos is located in the Central Administrative Center of São Paulo state (IGC, 2018), between $22^{\circ} 09^{\prime} 3^{\prime \prime}, 21^{\circ} 35^{\prime} 50^{\prime \prime}$ southern latitude $48^{\circ} 05^{\prime} 27^{\prime \prime}, 47^{\circ} 43^{\prime} 09^{\prime \prime}$ western 
longitude with 1,140 km2 (Figure 1) (IBGE, 2018). The local population is 236,958 inhabitants (population density of 208 inhabitants per $\mathrm{km}^{2}$ ) with the urbanization level of $96 \%$ and an annual population growth rate of 1.02 (SEADE, 2018).

The climate is characterized as tropical with dry winters. Cerrado (Brazilian Savanna) is the predominant biome. The average temperature approaches $21.12{ }^{\circ} \mathrm{C}$ and average monthly rainfall is $118.56 \mathrm{~mm}$ with a total annual of $1,422.8 \mathrm{~mm}$ (CEPAGRI, 2018).

The study area is characterized by Botucatu geomorphology related to Guarani Aquifer recharge area, the largest transboundary freshwater source in the world, with hydrography of the Tiete-Jacaré and Mogi-Guaçu sub-basins (Biota FAPESP, 2014). It is characteristic of this formation the presence of large stratification, being able to reach thicknesses and $20 \mathrm{~m}$. In these regions, the soils that are formed from the weathering of Botucatu Formation rocks are strongly related to their granulometry, being generally sandy and deep (EMBRAPA, 1999; Souza et al., 2017) with low slopes.

The land use of São Carlos is dominated by sugar cane plantations, with areas of bare soil, open water bodies, citrus plantations, pastures, forestry, urban areas and natural vegetation. Agricultural land use has expanded between 2003 and 2013, with an increase of $41.42 \%$ in cultivated areas, mainly sugar cane and citrus (Trevisan, 2015). In $2013,70 \%$ of the area was dominated by agricultural activities, with 33,550 ha occupied by sugar cane, 1,810 ha by forestry and 899 ha by citrus (Trevisan, 2015). The practices of sugar cane cultivation are associated with bare soil areas during the fallow period and preparation of the soil for the next crop cycle.

Areas of native natural vegetation are fragmented, with a loss of about $31 \%$ over ten years, representing 3,067 ha (Trevisan, 2015). These remaining fragments are embedded in the agricultural land use matrix and are mostly associated with water bodies, which are Permanent Conservation Areas. Urban areas were present in small proportions when compared to other land uses $(6,350$ ha in 2003 and 6,695 ha in 2013) (Trevisan, 2015), mainly because of the municipality's dependence on the agricultural sector.

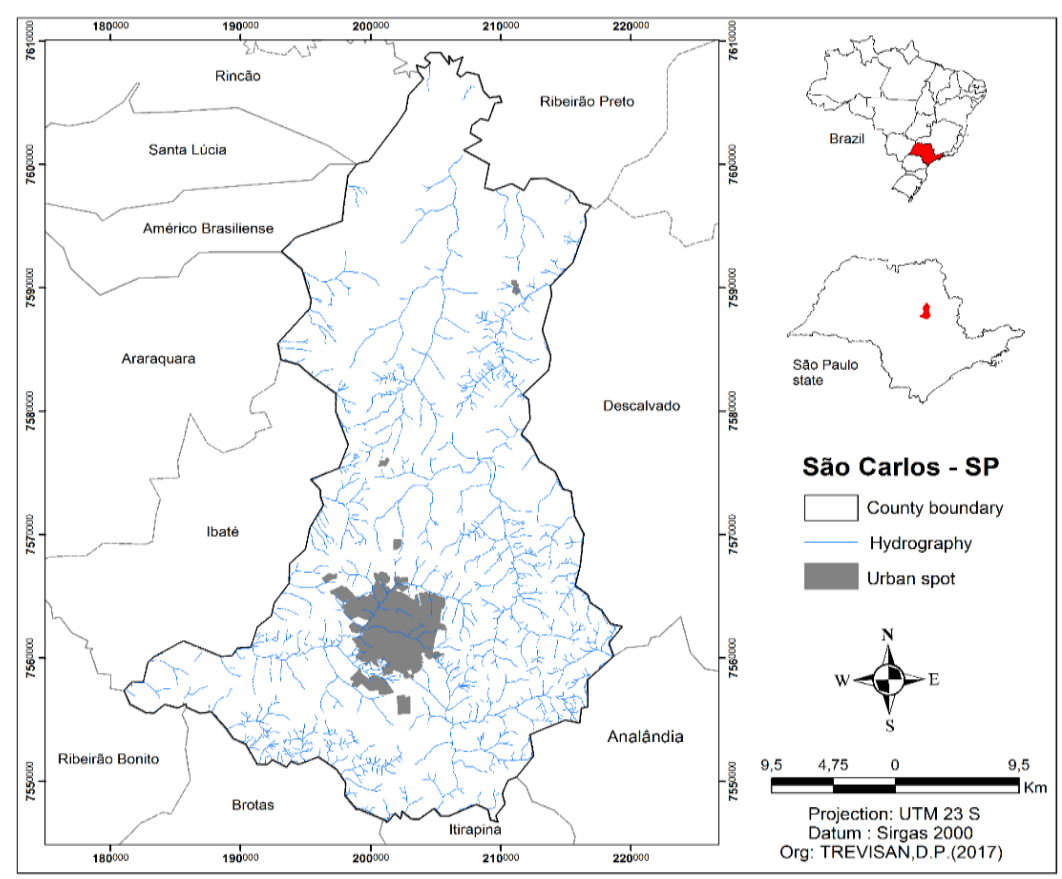

Figure 1: Geographical location of the Brazilian city, São Carlos (SP)

Methodology

Data analysis was carried out with Geographic Information Systems (GIS), using ArcGIS 10.3 and the GIS database of São Carlos was used to characterize the landscape using geographical UTM projection, Zone 23 South, datum SIRGAS 2000. Data of the São Carlos administrative boundaries were purchased from the
IBGE (Geographical Institute of Geography and Statistics) digital database and from the planialtimetric charts in analog form on a 1:50,000 scale, charts: SF-22-ZB-III-2, SF-23 IV-VC-1, VC-SF-23 IV-3, SF-23 Ya-I-1, SF-23 IV-VC-2, VC-23-SF-4 and IV-SF-23-YAI-2.

Two Landsat satellite images were obtained (orbit/frame 220/75, acquisition dates 30 April 
2003 and 21 September 2013). For 2003, Landsat 7 ETM+ images were used, bands $5 / 4 / 3$, and for 2013 Landsat 8 OLI/TIRS images were used, bands $6 / 5 / 4$. The use of images from different satellites was necessary due to the long study period. However, the scenes used in the study have the same spatial resolution of $15 \mathrm{~m}$ through panchromatic sharpening. The acquisition dates in April and September were chosen due to the seasonality of the prevailing agricultural practices in the region. The time gap of 10 years between the images allowed the study of the temporal patterns of the landscape.

The classification of land use and land cover was based on a multi-level classification system proposed by the Land Use Technical Manual (IBGE, 2013). In the primary hierarchical level I four classes were included that indicate the principal land use categories. The secondary hierarchical level II analyzed the types of land uses that were included in the first level. The tertiary hierarchical level III explained the land uses themselves (Table 1).

Table 1: Description of the land use and land cover classes.

\begin{tabular}{|c|c|c|}
\hline Class (I) & Type (II) & Description (III) \\
\hline $\begin{array}{l}\text { Area anthropogenic } \\
\text { and not agricultural }\end{array}$ & Urban areas & $\begin{array}{c}\text { Urban density area and areas with rural facilities (industrial and } \\
\text { household) }\end{array}$ \\
\hline \multirow{5}{*}{$\begin{array}{l}\text { Area anthropogenic- } \\
\text { agricultural }\end{array}$} & Sugarcane & Cultivation area of Saccharum officinarum L. \\
\hline & Citrus & Cultivation area of Citrus sinensis. \\
\hline & Pastures & $\begin{array}{l}\text { Area with a predominance of herbaceous vegetation (native or } \\
\text { exotic), used for extensive livestock farming. }\end{array}$ \\
\hline & Silviculture & Cultivation area of Eucalyptus $s p p$ or Pinus spp. \\
\hline & Soil exposed & Soil fallow area for Saccharum officinarum L. cultivation \\
\hline
\end{tabular}

Natural vegetation Natural Area with a predominance of shrub/tree vegetation, with vegetation vegetation types of semi-deciduous forest and Cerradão.

Water Water streams Large rivers, lakes, ponds, and reservoirs.

Landscape indices

Landscape indices were used to describe temporal landscape pattern resulting from the influence of anthropogenic land use processes in São Carlos between 2003 and 2013. This approach assumes that the relevance of the environmental impacts of the types of land use and land cover are associated with the vulnerability and sensitivity of landscape components. The indices in this work were adapted from Canter (1996); Eastman (1997) and Bojórquez-Tapia et al., (2002). Some authors such as Fushita et al., (2013), Bueno (2014) and Trevisan; Moschini (2017) also have developed and tested these indices in the Brazilian context.

Fuzzy logic was used in the analysis of the landscape indices to allow for the detection of intermediate transition states (Fisher; Wood, 1998; Marro et al., 2013).

A set of Environmental Quality Indices (EQI) was used to analyze the susceptibility of the ecological components to the effects of human activities (Bojórquez-Tapia et al., 2002). The EQI of Vegetation (EQI Bio) reflected the sensitivity of the landscape to the loss of biodiversity and habitat fragmentation resulting from the condition of the native vegetation class (Canter, 1996). The EQI Bio was obtained based on the analysis of the area (EQI Area), shape (EQI Shape) and distance (EQI Distance) between fragments of native vegetation (Equation 1):

$$
E Q I \text { Bio }=\frac{E Q I \text { Area }+E Q I \text { Shape }+E Q I \text { Distance }}{3}
$$

Information on the native vegetation class was used to estimate EQI Area (Eastman, 1997). The bigger the area of a fragment, the greater is the environmental quality in relation to biodiversity. Vegetation fragments with areas equivalent to 1 ha were considered of minimum quality $(\mathrm{EQI}$ Area $=$ 0 ), as fragments with areas higher than 1,000 ha were considered of maximum quality (EQI Area = $1)$.

The information on the native vegetation class was also used to estimate EQI Shape. The perim function was used to calculate the perimeter (P) of each fragment. (Eastman, 1997). The shape index $(\mathrm{SI}=0.25$. $\mathrm{P} / \sqrt{ } \mathrm{A})$ was applied using the 
image calculator module. This model was proposed by Valente (2001), and results in a thematic map where each fragment shows a value related to its shape. Thus, fragments with values near 1 , had a shorter edge length and higher environmental quality (EQI shape $=1$ ), while fragments with indices near 0 , showed lower environmental quality $(\mathrm{EQI}$ shape $=0$ ).

The distance module (Eastman, 1997) was used to estimate the EQI score related to distance (EQI Distance). The lowest degree of environmental quality was assigned to fragments further than $1,000 \mathrm{~m}$ away from the nearest neighboring fragment (EQI Distance $=0$ ), while the highest level of environmental quality was assigned to distances near zero (EQI Distance $=1$ ).

The susceptibility of water resources to land use impacts was quantified by the EQI for Water Resources (EQI Hydro). This index considers the impacts of the release of pollutants, the effects of pesticides, the transport of solid waste, and other factors resulting from human activities (Canter, 1996). EQI Hydro was determined based on the overlap of thematic maps of agricultural and non-agricultural human activities, obtained by reclassifying land use/land cover and the drainage network. The spatial representation was developed based on the use of the distance module on SIG-Idrisi (Eastman, 1997) and recreated based on fuzzy logic.

This analysis represents the distance of water resources in relation to impacting sources, assigning the minimum quality grade (EQI Hydro $=0$ ) to the rivers with a zero distance from the impacted areas. The maximum degree of quality (EQI Hydro $=1)$ corresponded to rivers with a distance from the impacted areas greater than 1000 $\mathrm{m}$.

Maintaining the integrity of natural ecosystems is at the heart of the development of the Environmental Landscape Vulnerability Index (ELV) since the ecosystem integrity is threatened by natural and human-made risks. Vulnerability and resilience are closely related, as the term vulnerability refers to the propensity to damage due to the lack of protection or at risk of being affected by a negative impact. Where the vulnerability is high, the resilience is considered low (Steffen et al., 2004).

The ELV determines the degree of susceptibility of the landscape to degradation by environmental impacts, expressing the landscape potential to absorb or be disturbed by human activity (Canter, 1996).

ELV was obtained (Equation 2) by calculating the mean of EQI Hydro and EQI Bio based on the image calculator module (Eastman, 1997). The greatest degree of environmental vulnerability of the landscape $($ ELV $=1)$ was ascribed to a state most susceptible to impacts, while the lowest degree of environmental vulnerability landscape (ELV $=0$ ) was assigned to a condition with the largest capability to absorb impacts (high resilience).

$$
E L V=\frac{E Q I H y d r o+E Q I B i o}{2}
$$

\section{Results and discussions}

The analysis of the EQI of Vegetation showed a decrease in environmental quality over time (Figure 2 and Table 2). These results are similar to studies published for other Brazilian regions (Moschini 2005, Dos Santos, 2011; Moraes et al, 2013; Junior; Hamada, 2015) that also showed the loss of areas of natural vegetation and the increase in impacts on the studied landscapes.

Trevisan; Moschini (2017) also documented an increase of urbanization, mainly due to the decrease of natural vegetation in Americana - São Paulo between 1994 and 2016. These characteristics coincide with the São Paulo State scenario, the largest producer of sugarcane in Brazil. Due to the growth of the domestic market, the favorable growing conditions, high soil and fertility, developed production assets for sugarcane, the average productivity is higher in São Paulo State than in other regions (Natale Netto, 2007; Martini et.al, 2018).

An increase in the number of fragments with low environmental attributes $(\mathrm{EQI} \mathrm{BIO}=0.0$ to 0.2) was observed, while the fragments with intermediate qualities (EQI $\mathrm{BIO}=0.2$ to 0.6 ) decreased in number. The fragments with high environmental quality ( 0.6 to 1 ) were maintained in terms of area, principally due these areas being related to water bodies and steep slopes preventing agricultural land use. The fragment in the southwest in Figure 2 is related to Tiete-Jacaré River, one of the most important rivers of the state and the fragment near the center of the municipality is related to Broa Seaside Resort and Lobo River, another important river in the region. 
Table 2. Environmental Vegetation Quality Index (EQI BIO) Values in São Carlos landscape (SP) for 2003 and 2013.

\begin{tabular}{rrrrr}
\hline \multirow{2}{*}{ EQI BIO } & \multicolumn{2}{c}{2003} & \multicolumn{2}{c}{2013} \\
\cline { 2 - 5 } & Area (ha) & \multicolumn{1}{c}{$(\%)$} & Area (ha) & $(\%)$ \\
\hline $0.0-0.2$ & $4,900.02$ & 20.49 & $6,455.39$ & 30.96 \\
\hline $0.2-0.4$ & $7,812.72$ & 32.67 & $5,028.85$ & 24.12 \\
\hline $0.4-0.6$ & $5,800.66$ & 24.25 & $3,959.92$ & 18.99 \\
\hline $0.6-0.8$ & $3,771.18$ & 15.77 & $3,773.34$ & 18.10 \\
\hline $0.8-1.0$ & $1,633.11$ & 6.83 & $1,633.11$ & 7.83 \\
\hline TOTAL & $23,917.69$ & 100.00 & $20,850.60$ & 100.00 \\
\hline
\end{tabular}

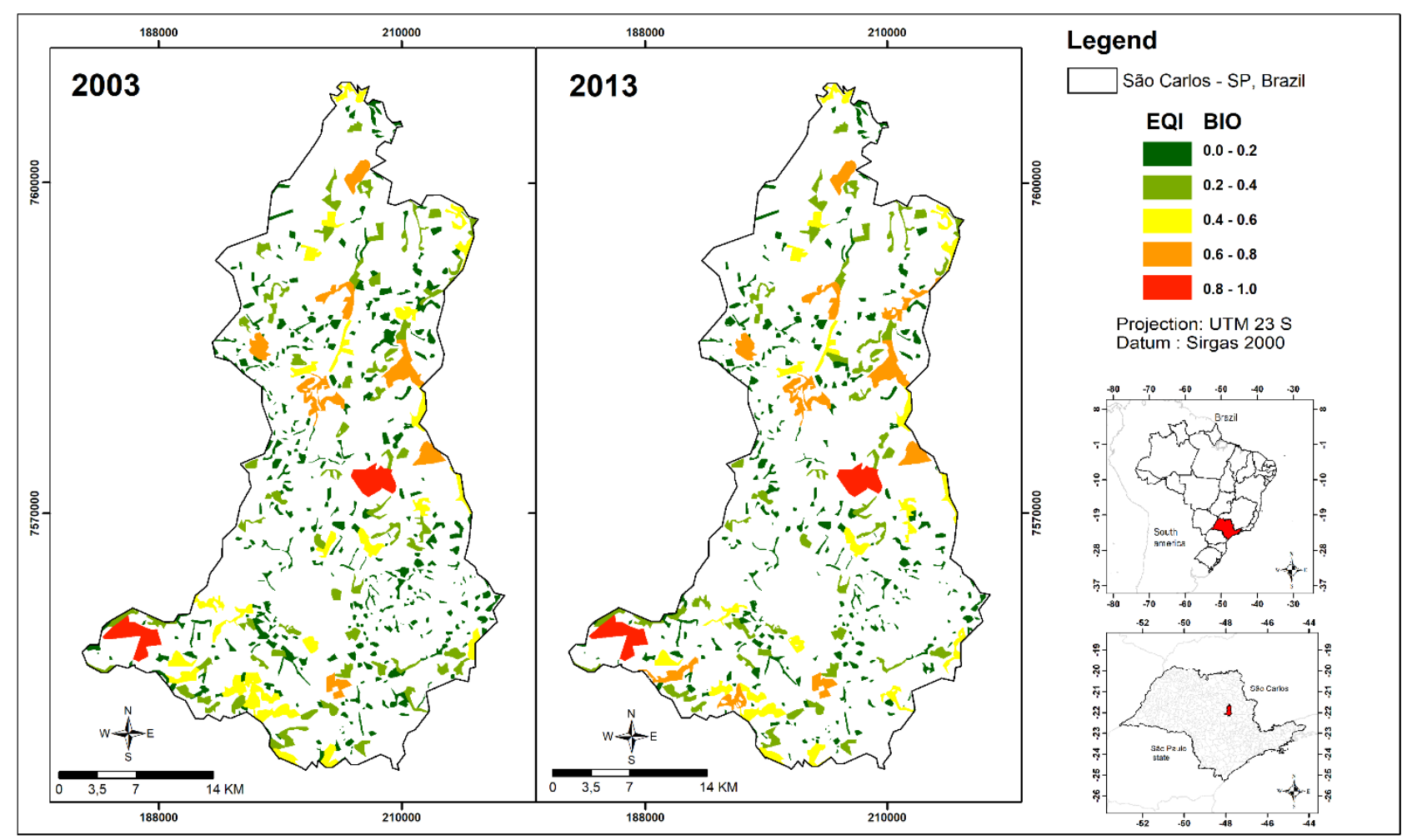

Figure 1: Environmental Quality Index of Vegetation (EQI BIO) in São Carlos landscape (SP) for 2003 and 2013.

The municipality, in addition to losing areas of natural vegetation, also lost the environmental quality of the remnants that remained over time. There was a loss of 3,067 ha of native vegetation between 2003 and 2013. This loss of forest fragments in the municipality of São Carlos was similar to findings from other areas (Cintra, 2004; Moschini, 2005; Moraes, 2013; Mello, 2014) which also identified the occurrence of fragmented landscapes due to unplanned land use and the consequent increase in the level of environmental vulnerability. Rego et al., (2018) reveal a loss of vegetation in São Luis Municipality - Maranhão, which is highly urbanized.

Considering that the Atlantic Forest and the Cerrado are two hotspots of rapid land use change, an immediate intervention to the ongoing fragmentation of the landscape is necessary. Mostly due to the advance of the agricultural frontier, more specifically by the cultivation of sugarcane, severe changes in the biological patterns of the landscape and the conservation of fauna and flora are happening in these habitats (Moraes et al., 2013).

These impacts compromise ecosystem structure and ecosystem services, e.g. through impacts on soils that support vegetation cover as the major sources of energy for terrestrial life (Bertoni; Lombardi Neto, 2008; Hernandez et.al, 2015). The uncontrolled land take and inadequate soil management have led to multiple environmental problems, such as soil compaction, decreased infiltration of rainwater and increased runoff. This set of factors favors the intensification 
of the water erosion process, which can evolve as laminar, groove or ravine forms (Silva, 2001; Medrano; Recaman, 2018).

The EQI of Water Resources follows the same trend as EQI Bio, which identified a decline in environmental quality. Table 3 and Figure 3 show an increasing number of fragments of low quality (EQI HYDRO $=0.0$ to 0.2 ), while the fragments of intermediate quality $(\mathrm{EQI} H \mathrm{HDRO}=$ 0.2 to 0.6$)$ increased and the fragments of high quality (0.6 to 1.0$)$ decreased.

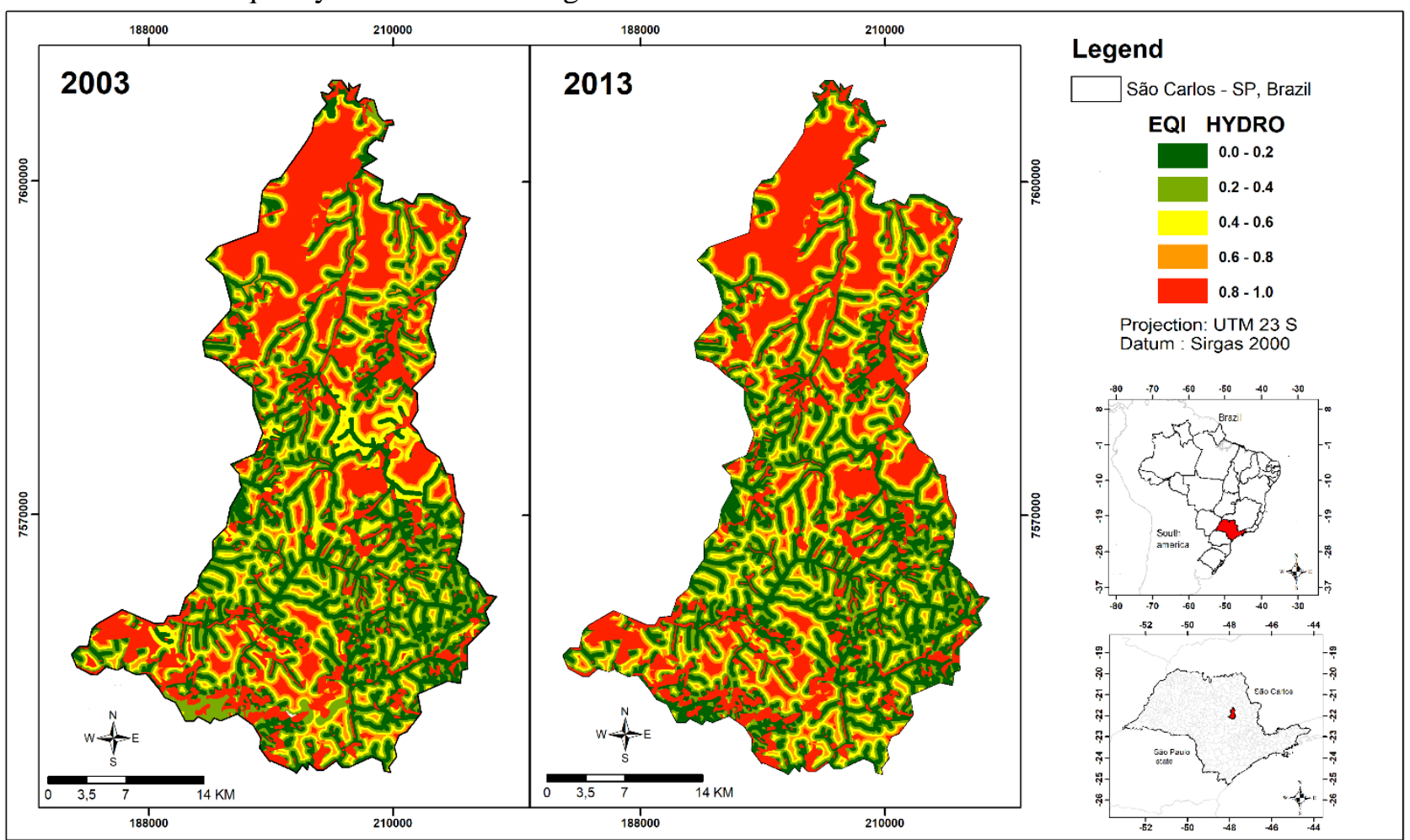

Figure 3: Environmental Quality Index of Water Resources (EQI HYDRO) in São Carlos landscape (SP) for 2003 and 2013.

Besides losing areas of natural vegetation, the municipality also witnessed a loss of the quality of the remnants that remained. The replacement of natural areas by agricultural and urban land uses contribute to the deterioration of the quality of its water resources through negative effects such as loss of riparian vegetation, sedimentation, and disposal of waste.

Table 3: Environmental Quality Index of Water Resources (EQI HYDRO) of the city of São Carlos landscape (SP) for the years 2003 and 2013.

\begin{tabular}{crrrr}
\hline EQI & \multicolumn{2}{c}{2003} & \multicolumn{2}{c}{2013} \\
\cline { 2 - 5 } HYDRO & \multicolumn{1}{c}{ Area (ha) } & \multicolumn{1}{c}{$(\%)$} & \multicolumn{1}{c}{ Area (ha) } & \multicolumn{1}{c}{$(\%)$} \\
\hline $0.0-0.2$ & $28,472.40$ & 25.0 & $29,472.40$ & 25.9 \\
\hline $0.2-0.4$ & $23,763.31$ & 20.8 & $25,763.31$ & 22.6 \\
\hline $0.4-0.6$ & $15,251.64$ & 13.4 & $16,251.64$ & 14.3 \\
\hline $0.6-0.8$ & $8,746.53$ & 7.7 & $7,746.53$ & 6.8 \\
\hline $0.8-1.0$ & $37,833.69$ & 33.2 & $34,766.60$ & 30.5 \\
\hline TOTAL & $114,000.00$ & 100.00 & $114,000.00$ & 25.9 \\
\hline
\end{tabular}

In the case of water resources management, the issue of declining water quality for domestic supply is due to the pollution caused by different sources such as household, industrial, urban and agricultural effluents. The contamination by industrial effluents is due to the raw materials and industrial processes used and may be complex concerning the nature, concentration, and volume of the waste produced. The degradation of the water sources mainly occurs because of the increase of the primary activity of the plants and algae caused by the nitrogen and phosphorus from 
farming and animal production (Merten; Minella, 2002; Musharafi et al., 2014).

The growth of algae and plants reduces the availability of dissolved oxygen in the water, adversely affecting the aquatic ecosystem and sometimes causing fish mortality. In addition to the impacts to aquatic ecosystems, increasing nutrient levels in water may jeopardize their use for domestic supply on account of changes in the taste and odor of water or the presence of toxins released by the flowering of some types of algae (Souza, 2005; Musharafi et al., 2014).

Another direct impact is related to the reduction of water resources, which is in some cases associated with the natural water balance through modifications of the hydrological regime. In many cases, the change in river flow is caused by anthropogenic actions such as the creation of canals in urban areas.

These data corroborate recent discussions about the water crisis in the 21st century, largely related to a lack of adequate management rather than to the real crisis of water scarcity and water stress. However, for some, it is the result of a set of environmental problems aggravated by other problems related to the economy and social development (Rogers et al., 2006; Wang, 2018).

There are several impacts related to the reduction of the drainage network, such as the modification of the hydrological cycle due to the reduction of soil infiltration and the replacement of groundwater and surface water or the appearance of floods in large and medium cities caused by the water bodies. Numerous authors such as Arai (2012) and Silva et. al (2016) have discussed the challenges of water resource management. Martins (2017) identified the need for the implementation and planning of the National Water Resources Information System in Brazil, focusing on the public managers responsible for its design and maintenance and representatives of civil society present at the National Water Resources Council.

The determination of environmental vulnerability is an important tool for developing strategies aimed at the ecological sustainability of the landscape since it identifies the areas that need immediate attention or that have a lower vulnerability. However, it should be noted that the Environmental Landscape Vulnerability Index (ELV) only considered the direct drivers of landscape change, namely agricultural and urban land uses.

The ELV (Figure 4) shows a trend of expansion of anthropogenic processes in the landscape due to the reduction of vegetation fragments over time, in which the remaining natural vegetation fragments, although preserving some ecological value, mostly become worthless for biodiversity protection, serving only as ecological corridors.

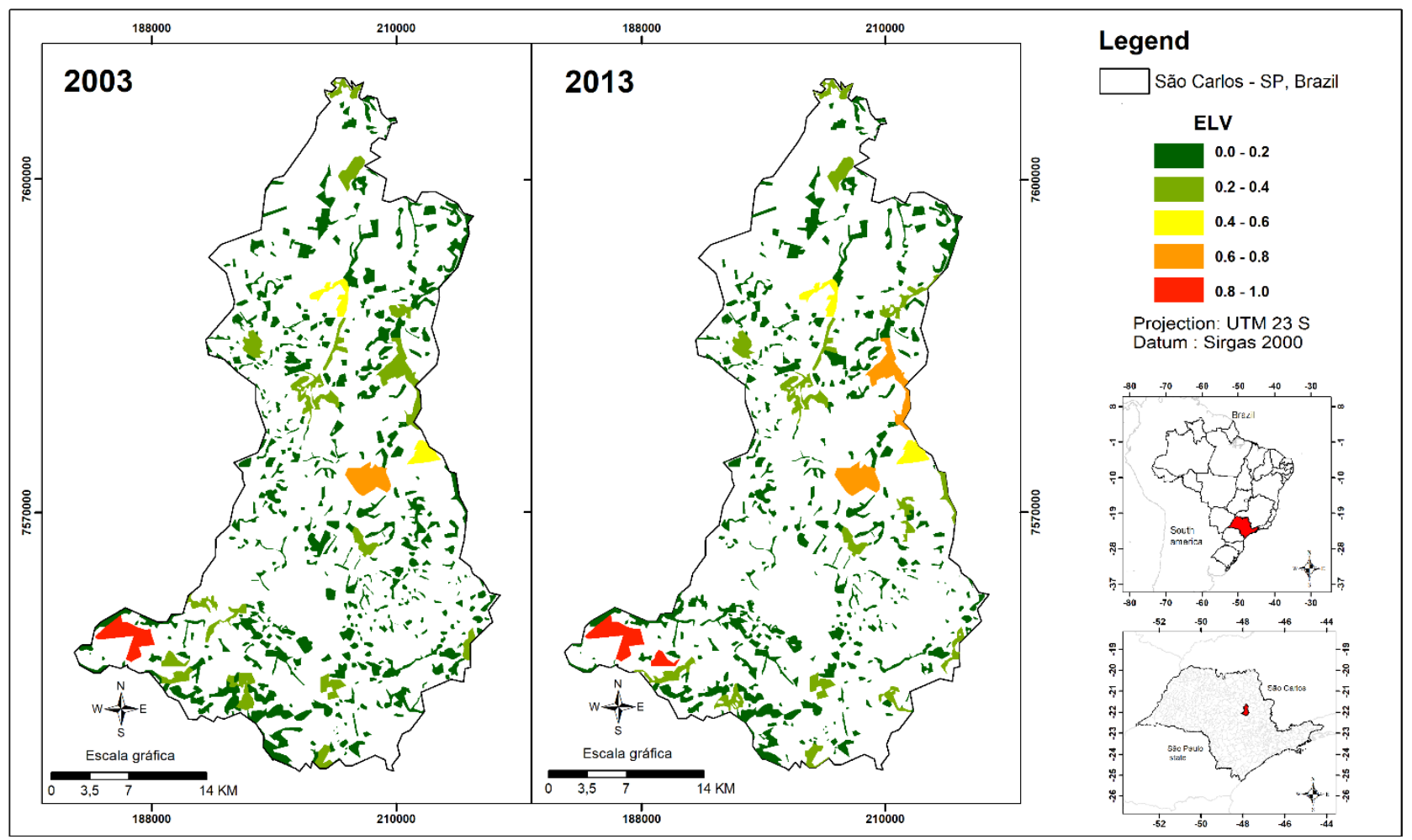

Figure 4: Environmental Landscape Vulnerability Index (ELV) in São Carlos landscape (SP) for 2003 and 
2013.

Lower ELV values from 0 to 0.2 represent areas with lower vulnerabilities (Table 4). Their frequency decreased from 2003 to 2013. This situation is different for ELV ranges from 0.6 to 1.0 , which increased in frequency from 2003 to 2013. Fragments were lost over time, particularly vulnerable fragments in 2003 were extinguished and converted for other land uses.

The degree of vulnerability remained high for the two periods studied. Especially in the vicinity of water bodies, where the rivers and streams remain the most vulnerable areas of the municipality, because of the proximity to human activities, especially agriculture.

Table 4: Environmental Landscape Vulnerability Index (ELV) in São Carlos landscape (SP) for 2003 and 2013.

\begin{tabular}{rrrrr}
\hline \multirow{2}{*}{ ELV } & \multicolumn{2}{c}{2003} & \multicolumn{2}{c}{2013} \\
\cline { 2 - 5 } & Area (ha) & \multicolumn{1}{c}{$(\%)$} & \multicolumn{1}{c}{ Area (ha) } & \multicolumn{1}{c}{$(\%)$} \\
\hline $0.0-0.2$ & $16,733.90$ & 69.96 & $13,241.00$ & 63.50 \\
\hline $0.2-0.4$ & $4,806.49$ & 20.10 & $5,218.74$ & 25.03 \\
\hline $0.4-0.6$ & 744.19 & 3.11 & 751.19 & 3.60 \\
\hline $0.6-0.8$ & 790.83 & 3.31 & 793.20 & 3.80 \\
\hline $0.8-1.0$ & 842.27 & 3.52 & 846.47 & 4.06 \\
\hline TOTAL & $23,917.69$ & 100.00 & $20,850.60$ & 100.00 \\
\hline
\end{tabular}

The areas with higher degrees of vulnerability are most environmentally susceptible to disturbances and have lower resilience. The entire landscape of São Carlos needs special attention in municipal planning, as $93 \%$ of the native vegetation area is in the ELV interval from 0.0 to 0.6 . Virtually all municipal green areas are highly vulnerable to land use impacts. The need for restoration and conservation of native vegetation areas is evident in order to reduce the degree of environmental vulnerability.

Only four fragments increased their connectivity. Very small fragments were converted to other land uses, and few of these have been grouped with other fragments, which would be ideal for an environmental restoration of the landscape.

In the Brazilian context, the importance of the areas of permanent conservation was legally supported by the Brazilian Forest Code of 1934 by Decree $n^{\circ} 23,793$ and later in 1965 by Law $\mathrm{n}^{\circ} 4,771 / 65$ and currently by Law $\mathrm{n}^{\mathrm{o}} 12,561 / 12$. The law defines that the riparian forest has the environmental function of preserving water resources, landscape character, geological stability, biodiversity, gene flow of fauna and flora, as well as soil, to ensure the wellbeing of human populations.

Despite the growth of human impacts on riparian ecosystems, in 2012 Brazil discussed whether to change the Forest Code of 1965 in order to reduce the restrictions and penalties imposed by it, through the Law Project 1,876, 1999. It generated the new laws 12,561 of 25 May 2012 and
12,727 of 17 October 2012, thus revoking the previous Forest Code of 1965.

The new Forest Code proposes changes regarding the calculation of environmental reserves within rural properties, decreases in permanent conservation areas (riverbanks, hills and mountains), decreases in the penalties imposed on those who deforest and cultivate agricultural crops in these properties (Observatório Do Código Florestal, 2015).

Studies conducted by the Institute of Applied Economic Research (IPEA, 2011) predict the possibility of about 79 million ha loss of natural vegetation, or $30 \%$ of the current legal reserve in the country. Considering the permanent conservation areas, this number would rise to hundreds of millions of hectares. The removal of these areas makes agriculture unsustainable in the short term (Tundisi, Matsumura-Tundisi, 2010; Comino et al., 2016), impairing economic activity.

According to IPEA (2011), approximately $76 \%$ of the productive land $(436,047,761$ ha of the total of $571,740,440$ existing ha) are owned by only $10 \%$ of landowners. In the short term, this inequality will cause irreversible damage to water quantity and quality thus endanger human health and food production (Likens, 1992, Singh et al., 2017).

It should be noted that environmental protection cannot be the exclusive task of the State, either through the executive branch institutes or through the judiciary, but should be backed by everyone's commitment, involving individuals, companies and civil society. A balanced 
environment must be guaranteed for the present and future generations (Pinto, 2009; Hanningan, 2017).

\section{Conclusions}

The EQI and ELV indices used are important tools for the diagnosis aimed at the conservation of ecosystems. They enable an accurate analysis of each landscape fragment where the loss of natural area directly involves a loss of quality of several interconnected compartments.

São Carlos immediately requires a plan aimed at maintaining the remnants of native vegetation. There is a need to give priority to conservation and restoration of these areas, considering not only the current state of the city but the developmental trend which has been following it.

The growth of human activities and the loss of natural areas can compromise the biodiversity present in the studied area, resulting in the loss of environmental functions and consequently the benefits they provide, considering that those areas serve as support for maintenance of urban and agricultural activities.

\section{Acknowledgments}

This research was supported by São Paulo Research Support Foundation (FAPESP) process $\mathrm{N}^{\circ}$ 2015/19918-3 and 2018/00162-4, European Union's Horizon 2020 research and innovation programme under the Marie Skłodowska-Curie grant agreement $\mathrm{N}^{\circ}$ 660020, Royal Society Wolfson Research Merit Award (2011/R3) and Natural Environment Research Council's National Centre for Earth Observation.

\section{References}

Arai, F. K., Pereira, S. B., Oliveira, F. C., Damália, L. S. 2010. Caracterização hidro morfométrica da bacia do Dourados localizada no centro sul do Mato Grosso do Sul. Agrarian. 5, 270-280.

Baró, F., Baggethun, E. G. Haase, D. 2017. Ecosystem service bundles along the urbanrural gradient: Insights for landscape planning and management. Ecosystem Services. 24, 147159.

Bertoni, J., Lombardi Neto, F. 2008. Conservação do solo. Sixth ed. Ícone. São Paulo, 150p.

BIOTA FAPESP. 2014. Sub-bacias hidrográficas do estado de São Paulo. Available: www.biota.org.br/info/saopaulo/bacias.
Access: 14 ago. 2018.

Bojórquez-Tapia, L. A., Juárez, L., Cruz-Bello, G., 2002. Integrating fuzzy logic, optimization and GIS for ecological impact assessments. Environmental Management. 30, 418-433.

BRASIL. 2013. Federative Republic of Brazil. Law $\quad \mathrm{n}^{\circ} 12.651 / 2013 . \quad$ Available: www.planalto.gov.br/ccivil_03/_Ato20112014/2012/Lei/L12651.htm. Access: 14 ago. 2018.

Bueno, B.P.S. 2014. Índices de urbanização e urbanidade em perspectiva histórica: São Paulo, 1798-1930. XIII - SHCU. Tempos e Escalas da Cidade e do Urbanismo. 1, 73 - 81.

Canter, L. W. 1996. Environmental impact assessment - Series in Water Resources and Environmental Engineering. Sixth ed. McGraw-Hill International Editions, New York.

CEPAGRI. 2018. Center for Meteorological and Climatic Research Applied to Agriculture. São Paulo state climate. Available: www.cpa.unicamp.br/outras-

informacoes/clima_muni_224.html. Access: 14 ago. 2018.

Cintra, R.H. 2004. Análise qualitativa e quantitativa de danos ambientais com base na instauração e registros de instrumentos jurídicos. in: Santos, J.E.; Zanin, E.M., Moschini, L.E. (Eds.). Faces da polissemia da paisagem: ecologia, planejamento e percepção. Rima. São Carlos, pp. 25 - 39.

Comono, E., Bottero, M., Pomarico, S., Rosso, M., 2016. The combined use of Spatial Multicriteria Evaluation and stakeholder's analysis for supporting the ecological planning of a river basin. Land Use Policy. 58, 183 - 195.

De Leo, G. A., Levin, S. 1997. The multifaceted aspects of ecosystem integrity. Conservation Ecology. 1, p.1- 16.

Dong, Y., Hauschild, M. Z. 2017. Indicators for Environmental Sustainability. 24th Conference on Life Cycle Engineering. 24, 697-702.

Dos Santos, R. M. 2011. Padrão temporal e espacial das mudanças de usos da terra e cenários para a conservação da biodiversidade regional do município de São Félix do Araguaia, MT.153f. Thesis (Ph.D. in Natural Resources Ecology). Federal University of São Carlos, São Carlos.

Duffy, J. E., Godwin, C. M., Cardinale, B. J. 2017. Biodiversity effects in the wild are common and as strong as key drivers of productivity. Nature. 549, 261 - 264.

Eastman, J. R. 1997. Idrisi for Windows. Tutorial Exercises. Version 2.0. Clark Labs for 
Cartographic Technology and Geographic Analysis. Clark University. Worcester.

EMBRAPA. 1999. Brazilian Agricultural Research Corporation. Oxisol. Available: www.agencia.cnptia.embrapa.br. Access: 14 ago. 2018.

Fisher, P., Wood, Jo., 1998. What is a Mountain? Or the Englishman who went up a Boolean Geographical Concept but Realised it was Fuzzy. Geography. 83, 247-256.

Franklin, J. F., Forman, R. T. T. 1987. Creating landscape patterns by forest cutting: ecological consequences and principles. Landscape Ecology. 1, 5-18.

Fushita, A. T., Reis, R. R., Faresin, L., Santos, J. E. 2013. Desempenho da classificação supervisionada em diferentes programas: comparação por meio do uso da terra e do índice de naturalidade da paisagem. Annals. XVI Brazilian Symposium on Remote Sensing SBSR, Foz do Iguaçu, PR, Brasil. INPE. 6463 6470.

Gardner, R. H., O’Neill, R. V. 1991. Pattern, process, and predictability: the use of neutral models for landscape analysis. In: Turner, G. M., Gardner, R. H. (Eds) Quantitative methods in Landscape ecology: the analyses and interpretation of landscape heterogeneity. First ed. Springer. New York. 289-308.

Goerl, R. F., Siefert, C. A. C., Schultz, G. B., Santos, C. S., Santos, F. 2011. Elaboração e aplicação de Índices de Fragmentação e conectividade da paisagem para análise de bacias hidrográficas. Revista Brasileira de Geografia Física. 5, 1000-1012, 2011.

Gustafson, E. J., Parker, G. R. 1992. Relationships between land cover proportion and indices of landscape spatial pattern. Landscape Ecology. 7, 101-110.

Hannungan, J. 2017. Disasters Across Borders: Borderlands as Spaces of Hope and Innovation in the Geopolitics of Environmental Disasters. Crossing Borders. 2, 79 - 94.

Hernandez, R. R., Hoffacker, M. K., MariscalMurphy, M. L., Wu, G. C., Allen, M. F. 2015. Solar energy development impacts on land cover change and protected areas. Proc Natl Acad Sci USA. 112, 13579-13584.

IBGE. 2013. Brazilian Institute of Geography and Statistics. 2013. Manual Técnico de Uso da Terra, $\quad 3^{\mathrm{a}} \quad$ Edição. $\quad$ Available: www.ibge.gov.br/home/geociencias. Access: 14 ago. 2018.

IBGE. 2018. Brazilian Institute of Geography and Statistics. São Carlos. Available: www.ibge.gov.br/cidadesat/painel/painel.php? codmun $=351930 \#$. Access: 14 ago. 2018.

IGC. 2018. Geographical and Cartographic Institute. Central administrative region. Available: www.igc.sp.gov.br. Access: 14 ago. 2018.

Inkoom, J. N., Frank, S., Greve, K., Walz, U., Furts, C. 2018. Suitability of different landscape metrics for the assessments of patchy landscapes in West Africa. Ecological Indicators. 85, 117 - 127.

IPEA. 2011. Institute of Applied Economic Research. Código Florestal: Implicações do PL 1876/99 nas Áreas de Reserva Legal. Brazilian Government. First ed. São Paulo.

Junior, C. S. M., Hamada, J. 2015. Analysis of urban impacts on aquatic habitats in the central Amazon basin: Adult odonates as bioindicators of environmental quality. Ecological Indicators. 48, $303-311$.

Malcolm, J. R., Valenta, K., Lehman, S. M. 2017. Edge effects in tropical dry forests of Madagascar: additivity or synergy? Landscape Ecology. 32, 327-341.

Marro, A. A., Souza, A. M. C., Cavalcante, E. R. S., Nunes, G. S. B. R. O. 2013. Lógica Fuzzy: Conceitos e aplicações, material didático. Annals. VII Ibero-American Congress of Educational Informatics. Federal University of Rio Grande do Norte. Natal. 127 - 136.

Martini, D. Z., Aragão, L. E. O. C., Sanches, I. D., Galdos, V. M., Silva, C. R. U., Nora, E. L. D. 2018. Land availability for sugarcane derived jet-biofuels in São Paulo - Brazil. Land Use Policy. 70, 256 - 262.

Martins, J. V. R. 2017. O Access à informação ambiental e a gestão hídrica: uma análise da implementação do Sistema Nacional de Informações Sobre Recursos Hídricos. Revista Eletrônica de Ciência Política. 8, 25 - 36.

Mateiro, B., Kastenholz, E., Breda, Z. 2017. The sensory dimension of the tourist experience in mountain destinations: The case of Serra da Estrela Natural Park. Revista Turismo \& Desenvolvimento. 27, 1- 12.

Mcgarigal, K., Marks, B. 1995. Fragstats Manual. Available: www.innovativegis.com/products/fragstatsarc/ manual/index.html. Access: 14 ago. 2018.

Medrano, L., Recaman, L. 2018. Space and society in the 21st century. The case of São Paulo. Bitácora Urbano Territorial. 28, 69-81.

Mello, K., Petri, L., Cardoso-Leite, E., Toppa, R. H. 2014. Cenários ambientais para o ordenamento territorial de áreas de preservação permanente no município de Sorocaba, SP. Revista Árvore. 38, 309-317. 
Merten, G. H., Minella, J. P. 2002. Qualidade da água em bacias hidrográficas rurais: um desafio atual para a sobrevivência futura. Agroecologia e Desenvolvimento Rural Sustentável. 3, 33 36.

Moraes, M. C. P., Toppa, R. H., Mello, K. 2013. A Expansão da Cana-de-Açúcar como fator de pressão para áreas naturais protegidas. in: Dos Santos, J.E., Zanin, E.M. (Eds.). Faces da Polissemia da Paisagem: Ecologia, Planejamento e Percepção. First ed. Rima. São Carlos. 163-173.

Moraes, M.C.P. 2013. Dinâmica da paisagem da Zona de Amortecimento do Parque Estadual de Porto Ferreira, SP. 92f. Dissertation (Masters in Sustainability in Environmental Management). Federal University of São Carlos. Sorocaba.

Moschini, L.E. 2005. Diagnóstico e riscos ambientais relacionados à fragmentação de áreas naturais e semi-naturais da paisagem: estudo de caso, município de Araraquara, SP. 88f. Dissertation (Masters in Natural Resources Ecology). Federal University of São Carlos. São Carlos.

Musharafi, S. K., Mahmoud, I. Y., Bahry, S. N. 2014. Environmental Contamination by Industrial Effluents and Sludge Relative to Heavy Metals. Journal of Geoscience and Environment Protection. 2, 14-18.

Natale Netto, J. 2007. A saga do álcool: fatos e verdades sobre os 100 anos do álcool combustível em nosso país. $1^{a}$ ed. Novo Século. Osasco, SP.

Observatório do Código Florestal. 2016. Brazilian Forest Code. Available: www.observatorioflorestal.org.br/paginabasica/o-codigo-florestal. Access: 14 ago. 2018.

O’Neill, R. V., Krummel, J. R., Gardner, R. H., Sugihara, G., Jackson, B., De Angelis, D. L., Milne, B. T., Turner, M. G., Zygmunt, B., Christensen, S. W., Dale, V. H., Graham, R. L. Indices of landscape pattern. Landscape Ecology. 1, 153-162.

Pena, S. B., Magalhães, M. R., Abreu, M. M. Mapping headwater systems using a HS-GIS model. An application to landscape structure and land use planning in Portugal. Land Use Policy. 71, 543 - 553.

Pinto, O. P. A. M. 2009. A Importância do desenvolvimento sustentável. Institute of International Law of Brasilia. Available: www.dcs.ufla.br/Cerrados/Portugues/CIntroP.h tm. Access: 14 ago. 2018.

Rego, J. C. L., Soares-Gomes, A., Silva, F. S. 2018. Loss of vegetation cover in a tropical island of the Amazon coastal zone (Maranhão Island,
Brazil). Land Use Policy. 71, 593 - 601.

Ridding, L. E., Redhead, J. W., Oliver, T. H., Schmucki, R., Mcginlay, J., Graves, A.R.; Morris, J., Bradbury, R. B., King, H., 2018. The importance of landscape characteristics for the delivery of cultural ecosystem services. Journal of Environmental Management. 206, 1145 1154.

Rogers, P. P. 2006. Water governance, water security and water sustainability. In: Rogers, P.P. (Ed.) Water crisis: myth or reality? London: Fundación Marcelino Botín, Taylor \& Francis. London. 3-36.

Schumaker, N. H. 1996. Using landscape indices to predict habitat connectivity. Ecology. 77, 12101225.

SEADE, 2018. Foundation State System of Data Analysis. Municipality Profiles. Available: www.seade.gov.br/produtos/perfil/perfil.php. Access: 14 ago. 2018.

Silva, L. E., Cruz, E. P., Junior, M. C., Almeida, R. R., Moura, A. A. 2016. Região Hidrográfica Do Atlântico Leste: Os Desafios Da Gestão Dos Recursos Hídricos. Ciências exatas e tecnológicas, Maceió. 3, 197-206, 2016.

Silva, V. C. 2001. Erosão atual, erosão potencial e aporte de sedimento na Bacia do rio Paracatu (MG/GO/DF). Thesis (Ph.D. in Geosciences). 108f. Geosciences Institute, Federal University of Brasília, Brasília.

Singh, N. S., Sharma, R., Parween, T., Patanjali, P. K. 2017. Pesticide Contamination and Human Health Risk Factor. in. Oves, M., Zain Khan, M., M.I. Ismail, I. (Eds.) Modern Age Environmental Problems and their Remediation, Springer. London. pp49-68.

Souza, E.F., Morassuti, C.Y., Soares, E., Duarte, G.S., Soares, G.S., Jorge, M.B., Silva, C.A.A., 2017. Classificação de solos e análise da vegetação em relação às características locais nos municípios de Dourados e Jateí/MS Soil classification and analysis of vegetation in relation to local characteristics in the cities of Dourados and Jateí/MS. Engevista. 19, 293305.

Souza, R. A. D. 2005. Avaliação das frações de fosfato como indicadores de eutrofização de águas superficiais. 124f. Dissertation (Masters in Agronomy). Federal University of Lavras, Lavras.

Steffen, W., Sanderson, A., Tyson, P. D., Jäger, J., Matson, P. A., Moore Iii, B., Oldfield, F., Richardson, K., Schellnhuber, H. J., Turner, B. L., Wasson, R. J. 2004. Global change and the earth system: A planet under pressure, SpringerVerlag Berlin Heidelberg, First ed. New York. 
Trevisan, D. P., Moschini, L. E. 2017. Evaluation of landscape urbanity in Americana, São Paulo, Brazil. International Journal of Development Research. 7, 16177 - 16183.

Trevisan, D. P. 2015. Análise das variáveis ambientais causadas pelas mudanças dos usos e cobertura da terra do município de São Carlos, São Paulo, Brasil. São Carlos. 80f. Dissertation (Masters in Environmental Sciences). Federal University of São Carlos.

Tundisi, J. G., Matsumura-Tundisi, T. M. 2010. Impactos potenciais das alterações do Código Florestal nos recursos hídricos. Biota Neotrop. 10, 67-76.

Turner, M., O’Neill, R.V., Gardner, R. H., Milne, B. T. 1989. Effects of changing spatial scale on the analysis of landscape pattern. Landscape Ecology. 3, 153-162.

Turner, M., Simard, M. 2017. Using Spatial Statistics and Landscape Metrics to Compare Disturbance Mosaics. in: Gergel, S.E., Tuner, M.G. Learning Landscape Ecology: A Practical Guide to Concepts and Techniques, First Ed, Springer, London, pp.175-190.
Turner, M. G.; Gardner, R. H. 1991. Quantitative methods in Landscape Ecology. SpringerVerlag, First ed, New York.

Turner, M.G., 1987. Spatial simulation of landscape changes in Georgia: a comparison of 3 transition models. Landscape Ecology. 1, 2936.

Turner, M. G. 1998. The effect of pattern on process. Landscape Ecology. 20, 171-197.

Turner M. G., Baker, W. L., Peterson, C. J., Peet, R. K. 1998. Factors influencing succession: lessons from large, infrequent natural disturbances. Ecosystems. 1, 511-523, 1998.

Valente, R. O. A. 2001. Análise da estrutura da Paisagem na Bacia do Rio Corumbataí-SP. 162f. Dissertation (Masters in Forest Resources). São Paulo University. Piracicaba.

Wang, Z., Zhong, R., Lai, C.; Zeng, Z., Lian, Z., Bai, X. 2018. Climate change enhances the severity and variability of drought in the Pearl River Basin in South China in the 21st century. Agricultural and Forest Meteorology. 249, 149 - 162. 